\title{
America, America!
}

\author{
Antoinette Molinié ${ }^{\star a d}$ and Geoffrey Bodenhausen*bcd
}

\begin{abstract}
This account was written during a four-month stay in Berkeley from May to August 2007. It was partly inspired by a diary published by Simone de Beauvoir after her four-month lecture tour to the US in 1947.[1] We could not resist the temptation of writing a few pages about our impressions. This text is not intended as an essay about anthropological or chemical sciences. We merely tried to understand the conditions of the bubbling creativity that we have so often witnessed in Berkeley. Some of our comments are more or less voluntarily naïve, as if Voltaire's Candide had made a trip to America. Our impressions may appear a bit franchouillardes, and perhaps a trifle rude to our American hosts, whose kindness does not deserve such a harsh treatment.
\end{abstract}

Keywords: Bibliometrics · Creativity · Cultural misunderstandings · Funding of scientific research · Impact

\section{The Original Plan}

Beyond the pursuit of science, we had two questions in mind: why are Berkeley's scientists so famous, and how do they manage to maintain their remarkable level of visibility? For there can be no doubt that in anthropology, chemistry, physics, and biology, Berkeley has some of the best-known departments in the world. By contrast, according to JMM's humorous appreciation, the Ecole Normale Supérieure (ENS) est surtout connue pour sa réputation ('is best known for its reputation'.) This selfdepreciating statement could be applied to any prestigious institution, including the

${ }^{*}$ Correspondence: Dr. A. Moliniéad, Prof. G. Bodenhausen bcd

aMaison de l'Archéologie et de l'Ethnologie (MAE)

Université de Paris $X$

21 Allée de l'Universite

92023 Nanterre Cedex, France

bDépartement de Chimie, associé au CNRS,

Ecole Normale Supérieure

24 Rue Lhomond

75231 Paris Cedex 05, France

Institut des Sciences et Ingénierie Chimiques

Ecole Polytechnique Fédérale de Lausanne

$\mathrm{CH}-1015$ Lausanne

dGuests of the Departments of Anthropology and

Chemistry

University of California

Berkeley, California 94720, USA

May-August 2007
University of California at Berkeley (UBC, or 'Cal' for short). But in contrast to his French colleagues, no American professor would ever risk such a wry ironical comment. In American academic circles, excellence is taken as a serious matter, au premier degré, without a trace of humour. In a similar milieu in France, self-derision is a paradoxical strategy of self-valorisation. Bonjour les malentendus culturels.

Pour un universitaire français, le milieu académique américain lève deux interdits. on peut ici parler d'argent, et traiter de la qualité intellectuelle des collègues. Le premier a probablement son origine dans l'uniformité de l'attribution financière pratiquée en France pour tout fonctionnaire et tout établissement. Pourquoi parler d'un salaire qui ne dépend que d'un indice, ou d'un budget qui reflète mécaniquement une enveloppe globale? Le deuxième interdit pourrait être une conséquence $d u$ souci égalitaire qui hante la petite bourgeoisie dont sont issus nombre d'universitaires français: il est malséant de juger un individu supérieur à un autre. On voit que ces deux tabous sont cohérents. Mais on peut aussi envisager qu'ils constituent un héritage aristocratique: les bien nés ne parlent pas des différences qui les distinguent, que se soit en argent ou en qualité. Ces deux explications sont évidemment compatibles.

Nos collègues américains, quant à eux, ne s'encombrent ni de pudeur financière $n i$ de sanction aujugement entre pairs. Les professeurs négocient leurs salaires et les sites web des universités proposent, dès la première page, de cliquer sur la rubrique 'faire un don'. Aux Etats-Unis, on est très prude sur les affaires sexuelles, mais très peu sur les montants financiers. L'hypocrisie est ainsi placée ailleurs qu'en France.

\section{Order and Disorder, Rigour and Creativity}

Asking the simple question of creativity ('how come that some people are inventive') opens a Pandora's box of tricky questions. To do a reasonable job in science, you need to have an encyclopaedic knowledge in areas such as anthropology, or master basic mathematical tools in physics. No matter whether you live in the US or in France, you need to be neatly organized, keep your filing system in good order, and be able to retrieve information of all sorts. But knowledge and organization are deadly enemies of imagination. So there is also a need for some degree of ignorance and disorder, otherwise creativity is bound to be stifled. But is ignorance a sufficient condition to be inventive? American and French scientists do not appear to agree on this matter. If you blurt out some unwarranted hypothesis, American scientists will barely listen, or, at any rate, quickly forgive, but in France similar errors may be considered as definite evidence of a lack of formal scholarship: an interesting debate will grind to a sudden halt when someone makes a minor mistake, about the date of a battle, the distance between two cities, etc. A Frenchman will gleefully point out your error, thus losing the thread of a discussion that could have become interesting. Americans not only forgive such minor errors: they seem not to perceive them, or deny having seen them, much to the relief of the foreign visitor and the quality of the discussion. 


\section{Social Skills and Generosity}

It is often said in Europe that Americans are superficial. This judgment cannot be upheld: on the contrary, many people in the US have uncanny skills to make you talk, to find out who you are, and what 'makes you tick'. Once they have a response, they may decide that they do not wish to see you again - which is their good right, and certainly no evidence of superficiality. We found many people to be remarkably generous, both with their heart and their purse. In France, I wouldn't dream of leaving the key to my office to a guest so that he can go through my personal library in my absence. Yet this is precisely what happened to AM thanks to SB's generosity.

Lagénérosité individuelle des Américains tranche remarquablement avec l'avarice sociale de leur nation. Les contacts humains ont une fluidité inconnue ailleurs et ils bénéficient d'une grande tolérance. On se livre plus vite en gestes ou en paroles, on apprécie votre accent étranger, et une simple 'introduction' vous permet de nouer une amitié confiante. Cet abord agréable est essentiel car il permet à l'étranger ne serait-ce que d'exprimer ses attentes, ses dispositions. En France la barrière de convenances qui semble régler l'approche d'un collègue étranger cache en réalité une absence d'étiquette: on a rejeté l'académisme ancien régime, et on ne sait plus s'il faut mettre une cravate pour la soutenance d'une thèse. Ce manque de règles doit être éprouvant pour nos collègues étrangers.

\section{Optimism and Confidence}

Perhaps the main strength of Berkeley's students is not so much their intelligence, formal education or skills, but their selfconfidence (CB). The students who delivered speeches at an intimidating 'Commencement' ceremony in the anthropology department indeed appeared to be radiating with self-confidence. This is a great asset! By contrast, some of France's most brilliant students - the ENS has no shortage of them - are strikingly humble, if not outright timid. In academic circles, modesty is something of a national virtue in France, although this is perhaps less obvious when watching intellectuals who turn up in TV shows. Modesty and self-effacement are hardly helpful to work one's way to the top of the podium of international science.

Il ne s'agit pas simplement de confiance en soi mais d'auto-valorisation. Celle-ci semble être perçue comme positive et même nécessaire dans le milieu académique de Berkeley alors qu'en France (et encore plus en Espagne) le moindre signe d'auto-

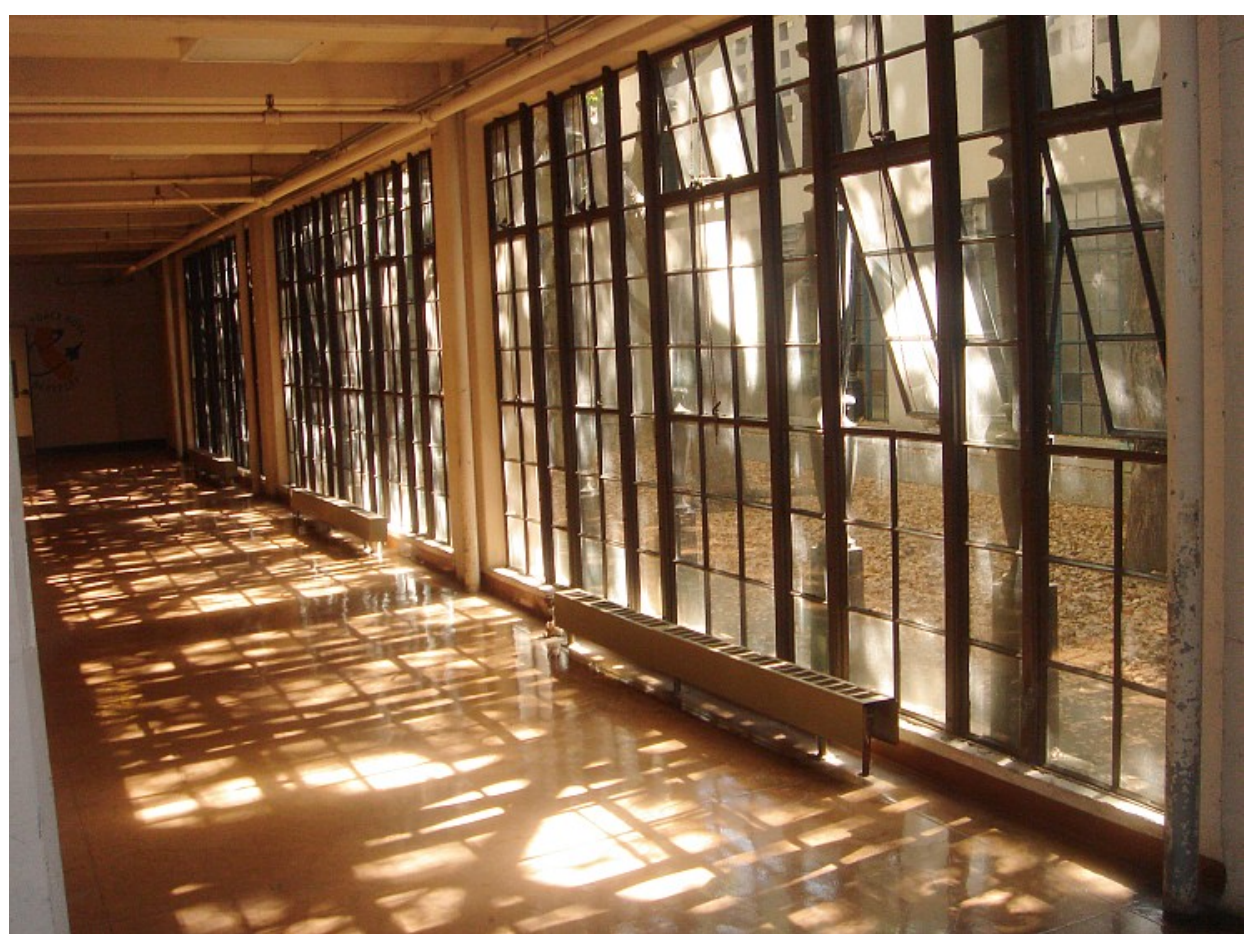

A sample of brilliant architecture on the UC Berkeley campus: the Hearst gym which has a wonderful marble-clad open-air swimming pool on its roof

satisfaction intellectuelle est considéré comme ridicule. Aux Etats-Unis, ne pas se mettre en avant est une caractéristique un peu méprisable de 'loser', alors qu'en Europe il s'agit simplement de décence. Cette différence peut donner lieu à des malentendus considérables. L'Américain pourrait soupçonner que le flagellant français est à la pêche d'un compliment, alors que ce dernier a tellement intériorisé l'interdit de s'exhiber qu'il souffre quand on exige de lui un peu d'estime de soi.

\section{Hype, Impact Factors, and Citation Indices}

In a few months, we met people who published more papers in famed journals such as Nature and Science than we ever did in humble series like the Journal de la Société des Américanistes or Applied Magnetic Resonance. They obviously know how to work the system. We expected this to be accompanied by a great deal of cynical 'hype'. There is indeed some hype, but we could not detect any cynicism. Nor did we meet many people who believe that citation indices are a satisfactory measure for excellence. Many agreed with our view that such statistics (which are useless for social sciences anyway) are often used as a cheap substitute for a serious evaluation. The authorities in France and in Switzerland appear to be running behind when they emphasize citation indices and 'bibliometrics': the US is already moving beyond. Wisely.

\section{Excellence}

In his remarkably humble manner, $\mathrm{CB}$ mentioned that he spent much time in polishing his papers ('up to 39 drafts' for one of his many papers in Science). In his Commencement address, AP offered a wonderful quotation from William Butler Yeats:

\section{A line will take us hours maybe;}

Yet if it does not seem a moment's thought, Our stitching and unstitching has been naught.

Indeed, there is a great deal of evidence of hard work in Berkeley. The group seminars run by AP, GS, GF, RG, JWC and others (which they kindly invited me to attend) are regarded as serious events. RG's group seminars are scheduled on Monday evenings from 7 to $9 \mathrm{pm}$. One cannot imagine anything like this in France, were it is de bon ton to appear neglectful, turn up late at seminars, and ask questions that are only vaguely related to the speaker's topic. This appears to reflect a near-aristocratic attitude to science.

On the other hand, while in Berkeley, we did not see much evidence of the intellectual brio, the profound understanding of mathematical and physical principles that one can witness at the Ecole Normale, particularly in our Séminaires de Physique Générale. Generally speaking, European students and post-docs do not have much reason to envy the intellectual level of their American counterparts. This observation applies not only to the ENS, but also to the 


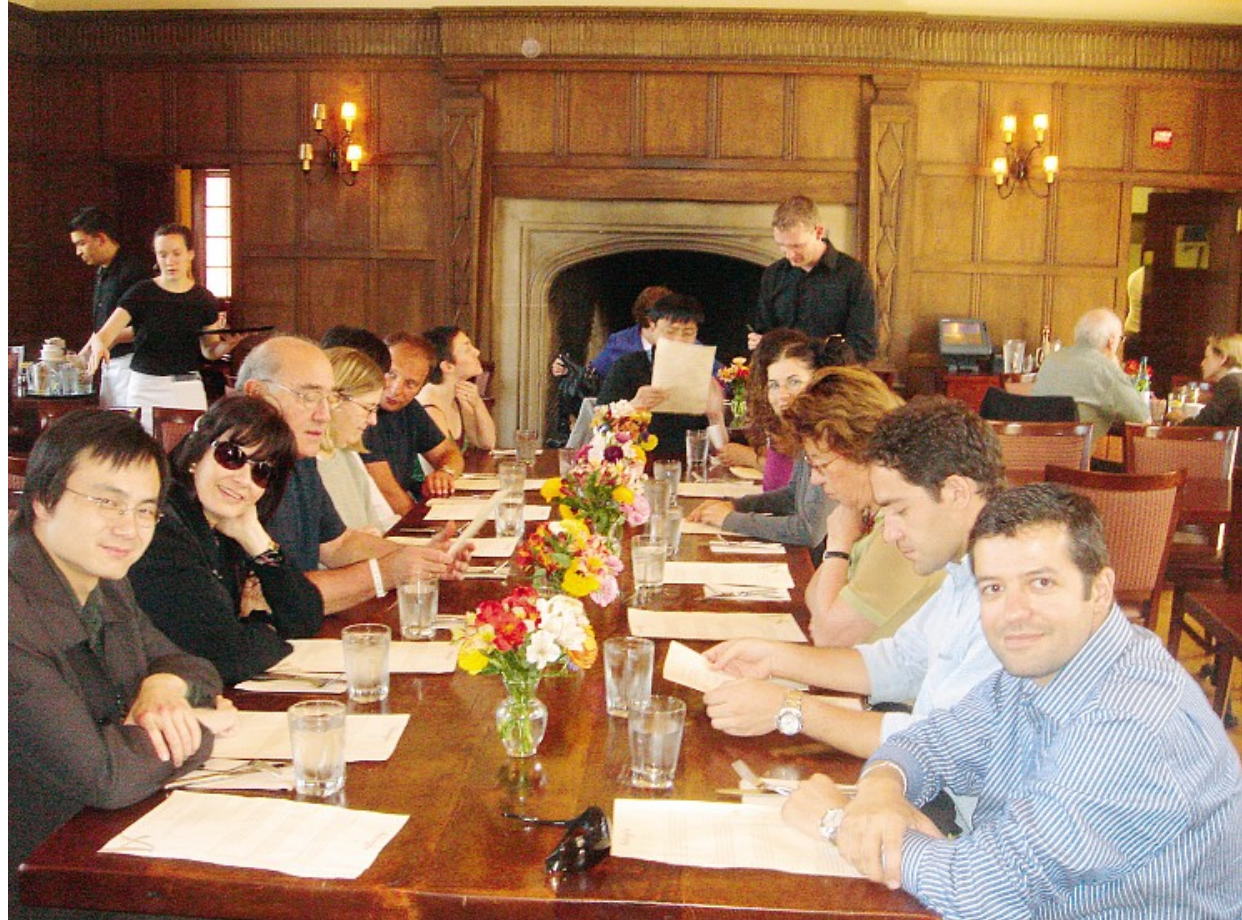

Group luncheon of some of the 'Pinenuts' at 'Adagio'. Ditsa and Alex Pines are second and third from the left. Former post-doctoral associate Dimitri Sakellariou is on the far right. One of the authors is third from the right.

Université de Pierre et Marie Curie (Paris-6) and to the EPFL in Lausanne.

For the faculty, the situation is entirely different. Rarely have I seen such confidence, such enthusiasm, such a strong identification with the institution, such a sense of solidarity with colleagues. French professors seem to be a sorry lot by comparison: often complaining, depreciating the system to which they belong, and forever critical if not outright jealous of each other.

L'université de Berkeley semble avoir une culture propre, un peu comme une entreprise ou un lignage. Elle a ses 'Bears', ses uniformes frappés du sigle ' $C A L$ ', son 'gourmet ghetto', son 'faculty club', ses rites d'initiation lors des 'Commencements'. Ceux-ci sont marqués d'un esprit de famille au sens propre: les parents des initiés jouent en effet un rôle important dans ces rituels. D'ailleurs tout parent d'étudiant peut faire un don à la grande famille qui devient ainsi la sienne. Parfois on a aussi l'impression d'être dans un couvent, tel celui de l'abbaye de Thélème de Rabelais, avec ses novices, ses moines illuminés et ses riches bibliothèques. Dans ce sens, l'Université de Berkeley est plus proche de la Sorbonne traditionnelle qu'aucune des universités françaises modernes.

En effet celles-ci apparaissent plutôt comme les organes peu différenciés d'une énorme structure d'enseignement supérieur. La spécificité, quand elle existe, est définie plutôt par discipline, au niveau de chacun des départements. Les ethnologues fran- çais parlent des 'Nanterrois' pour désigner le département d'ethnologie de l'université de Paris $X$ à Nanterre, mais aucun terme équivalent n'existe au niveau de l'ensemble de cette université. Aucune cérémonie ne regroupe l'ensemble des disciplines, hormis les réunions des conseils d'administration dont les activités ne sont guère festives. Certes un Président gère l'ensemble; mais seuls l'abstention à son élection et le mécontentement font l'unanimité. Il n'existe pas d'équipe sportive ou de manifestation culturelle. La cantine est un désert gastronomique, à l'opposé du 'gourmet ghetto' de Berkeley, et la plupart des professeurs préfèrent s'alimenter au four micro-ondes de leur département tout en se bouffant le nez.

\section{Responsibility}

In the old days, as RB told me, professors were treated with suspicion by the American society at large because they were reputed to be well paid, enjoy the security of tenure, and have little teaching to do. More recently, the situation has changed, since is it now increasingly recognized that their inventions contribute significantly to the growth of the gross national product. Thus the brand-new Stanley Hall, the latest addition on UCB campus, has been funded in large part because of anticipated fall-backs of 'quantitative biology' on California's economy (AJ). Of course, this is no minor responsibility: the social status has risen, but so have the expectations.
It is remarkable how the faculty at UCB consider it to be their responsibility to find the best possible academic or industrial jobs for their graduate students. In a sense, UCB plays a similar role for the US as the ENS for France, i.e., it is the prime source of highly qualified faculty. Of course, neither UCB nor ENS claim to hold a monopoly (the US being too large and diverse to rely on a single school, and the ENS too small to fill all academic positions in France), but the spirit is similar. The normaliens also cultivate something akin to un esprit de famille. In this respect, the grandes écoles are quite distinct from the French universities.

Another analogy can be found in the dedication of UCB faculty to higher education as a public service. Although the UCB campus has received many contributions and donations from private funds in the course of the years (and continues to do so), higher education in California appears to be almost unique in the US in the sense that private schools do not play a major role here, with some notable exceptions like Stanford, CalTech and the University of Southern California, which however represent a only few percent of the student body. UCB stands proud in contrast to the Ivy League of the East Coast. Unfortunately, California's middle and high schools hardly meet these tough standards. Professors jokingly complain about the ignorance of the 'teenagers' who are being sent to UCB for undergraduate education by California's high schools. By contrast, graduate students are recruited from across the country.

Private funding, which is frowned upon in France, is one of the main sources of wealth for many American universities. In France, the universities are supported by the State - and if the State can no longer afford to sustain them, they might as well wither away. It is the State - expression of a bourgeoisie that has taken over the leadership from the aristocracy at the time of the French revolution - that must carry sole responsibility for the education system and guarantee the sacred 'égalité' of the citizens. Direct private funding would taint the purity of knowledge. The very idea that knowledge can have a market value appears nearly immoral in France. The absence of generous foundations goes a long way towards explaining the impoverishment of the French academic system.

\section{Management of the University}

The followed text was found pinned to the wall in a chemistry laboratory:

\section{New element discovered}

The heaviest element known to science was recently discovered by physicians at Whatsamata $U$. The element, tentatively 
named Administratium, has no protons or electrons and thus has an atomic number of 0 . However, it does have 1 neutron, 125 assistant neutrons, 75 vice-neutrons, and 111 assistant vice-neutrons. This gives it an atomic mass of 312 . These 312 particles are held together in the nucleus by meson-like particles called memos. Since it has no electrons, Administratium is inert. However, it can be detected chemically as it impedes every reaction it comes in contact with.

According to the discoverers, a minute amount of Administratium caused one reaction to take 4 days to complete when it would normally take 1 second. Administratium has a normal half-life of approximately 3 years, at which time it does not actively decay, but instead undergoes a reorganisation in which the assistant neutrons, vice-neutrons, and assistant vice-neutrons exchange places. Some studies have shown that the atomic mass number actually increases after reorganisation.

Research at other laboratories indicates that Administratium occurs naturally in the atmosphere. It tends to condense and concentrate at certain points such as government agencies and universities, and can usually be found in the newest, bestappointed, and best-maintained buildings.

Scientists point out that Administratium is known to be toxic at any level of concentration, and can easily destroy any productive reaction when it is allowed to accumulate. Attempts are being made to determine how Administratium can be controlled to prevent irreversible damage, but results to date are not promising.

Some seniors like JR felt that the secret of the self-governance of UCB lies in the rigorous enforcement of term limits (a Dean can be re-elected only once, so that his maximum term is six years). As a result, rotation occurs quite naturally, and no Dean can afford to develop dictatorial attitudes, for fear that he may become a victim himself at the end of his term.

Les Deans américains sont peu comparables aux ex-doyens français devenus présidents: il y a plusieurs Deans dans une université Américaine, et les découpages sont surprenants pour nous (par exemple, une Dean des 'graduate studies' a sous sa responsabilité l'ensemble des écoles doctorales). Les Deans semblent avoir peu de pouvoir sur le plan académique.

\section{Management of the Country}

In France, the slightest disaster, be it a storm, flood, or avalanche, is thoroughly exploited by the media to demonstrate the protecting power of the State (Etat always being spelled with a capital): the TV news shows scores of ambulances, fire-trucks, police cars and helicopters. Likewise, anything that works smoothly, be it the post office, the railways, the public health system, etc. is invariably attributed to the wisdom of the good people who govern us. In France, the State has come to be perceived as a permanent feature of the environment, as if it

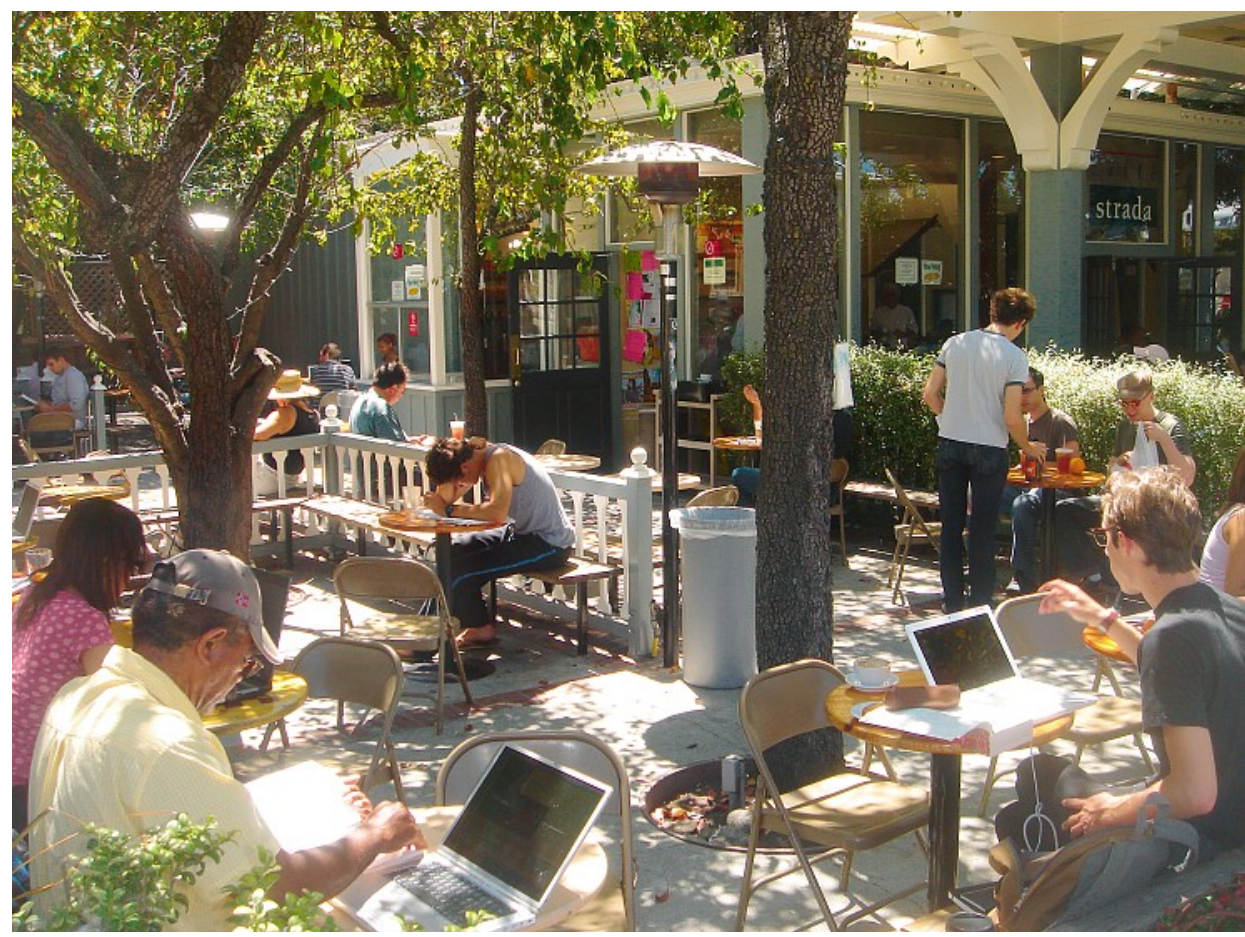

Berkeley students with their laptops on the open-air terrace of café 'La Strada', across Bancroft avenue near the campus of the University of California at Berkeley were part of nature rather than a manifestation of culture. In the US on the other hand, it seems that natural catastrophes such as hurricanes, earthquakes and collapsing bridges serve to demonstrate (though perhaps not deliberately) that the Administration (one rarely says 'government' here) is not going to help you out, and that you better rely on yourself. In AJ's words, the people who have now been trusted with running the state are not only skeptical about the very need for a state, but many of them are dedicated to its demise.

Derrière cette divergence se cache peut-être une différence dans la limite instaurée entre la nature et la culture. On note aux USA une tendance à placer dans le domaine de la nature les maux issus des inégalités sociales ou des déficiences de l'Administration'. Certes, la catastrophe de New Orleans avait une origine naturelle. Mais à lire la presse qui en célèbre le triste anniversaire, on a l'impression que l'absence de l'Etat était dans l'ordre des choses: comme l'ouragan, l'incurie des services était 'naturelle'. A l'inverse, dans un chemin de randonnée, un élément $d u$ paysage, une cascade par exemple, sera indiqué par une affiche qui mentionnera 'CASCADE' de la même manière qu'on indiquerait 'TABLE LOUIS XV' dans un salon du château de Versailles: comme si, en signalant un phénomène naturel par un panneau, on le faisait entrer dans le domaine de la culture, ou, plus généralement, de la construction humaine.

En revanche en France le service de l'Etat semble apparaître comme un phénomène naturel qui devrait, par exemple, prévenir toute catastrophe: 'que fait le gouvernement?' dira t-on en période de canicule mortelle, comme on dirait 'quand la pluie viendra-t-elle nous rafraîchir?'. Une manifestation violente est 'naturelle' comme devrait l'être sa répression: 'que fait la police?' A l'inverse des Etats Unis où l'absence de l'Etat est dans la nature des choses, en France l'entretien des monuments nationaux, la construction d'une Grande Bibliothèque, un enseignement secondaire professé par des agrégés surqualifiés, ou encore la couverture universelle d'assurance-maladie apparaissent quasiment comme des éléments de la nature. C'est ainsi que la faillite de l'université française est souvent présentée comme une catastrophe naturelle.

Il est intéressant de noter que pour les Français, 'administration' (soit l'équivalent de l'Etat pour les Américains) et 'Etat' sont des notions divergentes quant à leurs valeurs: à l'action nocive de la première s'opposent les bienfaits et les attentes de la seconde. A tel point qu'un roi de France a pu dire 'L'Etat c'est moi', alors qu'on voit mal un président 
des Etats-Unis déclarer 'I am the Administration'. Il semble en effet qu'ici on ne fasse pas clairement cette différence entre administration et Etat. C'est ainsi qu'un Américain distingue mal l'un de l'autre les deux corps, profane et sacré, de l'Etat, dans le sens que Kantorowicz a donné aux deux corps du roi.

\section{Puritanism}

In the swinging sixties, California (and Berkeley in particular) had a reputation of breaking rules of elementary decency (as Antonioni immortalized in 'Zabriski point'). Today, it is striking how any 'public demonstration of affection' is suppressed. If you see a boy and girl holding hands, you can be sure that they are foreign visitors. On campus, you never see the slightest glance, much less any flirtatious behaviour. On the sunny terrace of the café ' $\mathrm{La}$ Strada', boys and girls assiduously surf the web on their laptops. Freud taught us that sublimation is one of the foundations of civilisation. Re-directing ones' libido from sex to intellectual endeavour is one of his best examples. At the swimming pool (where there is no shortage of healthylooking boys and girls), there is a sign 'bathing suits must be worn at all times - California Public Health Code' (our italics). It is hard to believe that San Francisco is often regarded as a sort of modern Sodom. Berkeley seems closer to the ideal of the Abbaye de Thélème described by the Renaissance poet and humanist Rabelais, a paradise of sublimation on earth. Berkeley peut-elle être vue comme une 'usine à sublimer'?

\section{Resilience and Conservatism}

The US academic system is remarkably resilient. As JS noted, ideas like the juxtaposition of major and minor subjects, the grading scales, the tenure track system, and many other aspects have survived the turmoil of the sixties unscathed. JS, who once upon a time was a major player in the 'revolutionary' Free Speech Movement (FSM) of the sixties and seventies, seems to take a secret pleasure in its failure to bring about any significant changes. The resilience of the academic world reflects the resilience of the political system. Constant references to the US Constitution give this founding text the appearance of near-mythical timelessness. In the two centuries since it was written, the French have been working their way through at least eleven regimes: five republics, four kings and two emperors. Is this as a mark of instability, or evidence of constant adaptation to a changing world?
Quand on entend les universitaires de Berkeley se plaindre de l'impossibilité de changement politique et social dans leur pays, on a l'impression qu'ils sont finalement assez satisfaits de cette situation: comme s'ils cherchaient à se rassurer de la pérennité de leur statut à travers la vaine provocation d'une révolution. Mais n'avons-nous pas cherché le même réconfort en France en ce mai 68 dont on dit encore qu'il a changé le cours de l'histoire? Les universitaires français ont fait mieux: par leur insubordination individualiste, ils ont invité les prolétaires à faire progresser le capitalisme d'Etat vers un capitalisme libéral sans frontières. Les accords de Grenelle auxquels la 'révolution' de mai 68 a conduit ne consistent en rien d'autre qu'en l'ouverture d'un marché de la liberté non pas tant aux ouvriers qu'aux artefacts qu'ils fabriquent, pour le plus grand bonheur de ceux qui les vendent, qui sont d'ailleurs souvent les parents des 'révolutionnaires'. Le bon bourgeois à Berkeley est rassuré par les yeux bridés des étudiants. le marché de la connaissance s'est ouvert grâce à la publicité que ces étrangers ont donnée à l'université. A présent, celle-ci est ouverte à toute l'Asie, désormais clientèle de l'institution. Les sous-développés, qu'ils soient Américains ou Asiatiques, s'arrangent entre eux. Les premiers forment les élites des seconds sous le sceau de la science universelle et impartiale. C'est la mission du département d'ethnologie où l'on n'étudie plus les «sauvages» mais l'ensauvagement des sociétés que l'on veut soumettre, telle que celle des néo-Indiens ${ }^{[2]}$ du Pérou et du Mexique... Les seconds payent leur accès au marché du futur par des gestes généreux. C'est ainsi qu'un collègue exprime sans ambages sa satisfaction d'avoir tant d'étudiants asiatiques: en effet les parents de ceux-ci font des donations considérables à la grande famille de Berkeley, contribuant ainsi à assurer sa future retraite, par ailleurs drapée dans la toge respectable du service public. Ces étudiants venus d'Asie sont clean et cool, contrairement aux afro-américains (comprenez Noirs) trop rebelles, ou aux Arabes trop arrogants. Les Asiatiques se déguisent volontiers en Bears, et on peut leur vendre une peau d'ours qu'ils ont dûment achetée: leur altérité est tolérable. Contrairement aux Musulmans à qui l'on a promis un Allah difficilement compatible avec une équipe de Bears mal léchés, leur conscience ethnique s'est dissoute dans le savoir sans couleur de l'académie.

\section{The Embarrassment of Politics}

Many encounters at UCB started with some embarrassed apology by our hosts. The current government is perceived by many academics as a threat to the relationship between the US and the rest of the world. Some intellectuals like Chalmers Johnson ${ }^{[3]}$ see the unprecedented level of corruption that has taken hold of Washington as an indication of the beginning of the end of the American republic. A few 'liberals' (roughly equivalent to gauchiste, not to be confused with an advocate of a deregulated économie libérale) go much further and speak of a military dictatorship under a civilian disguise. Other respectable professors such as RB do not hesitate to compare today's US government with Germany in the thirties. A great deal of enthusiastic 'Bush-bashing' is often followed by statements that all things will get better after the next presidential election. There seems to be little space for the idea of systemic failure in American political thinking.

On peut s'étonner de l'habitus politique des universitaires que nous avons rencontrés, et en particulier du gouffre qui sépare leur intelligence scientifique et le niveau modeste de leurs analyses politiques. Leurs propos portent plus souvent sur les individus que sur les structures. On parle beaucoup de la stupidité de Bush mais pas du régime qui a porté cette stupidité au pouvoir: le système électoral américain, par exemple, avec ses délégations de vote aux grands électeurs doit probablement jouer un role. Par ailleurs, il n'est point ici nécessaire d'être préparé à gouverner, que ce soit par une éducation royale à la cour (avec un Colbert, un Mazarin, ou un Richelieu), ou par une éducation républicaine dans le serail de l'Ecole Nationale d'Administration (ENA). L'idée que même qu'un acteur puisse gouverner ce pays (et le monde!) paraît très étrange en France. Aux USA, elle ne choque pas même les universitaires: ils sont frappés par la bêtise de leur président sans même songer au système qui la produit. C'est évidemment le rôle de l'argent dans la promotion présidentielle qui doit être questionné. Il en faut beaucoup pour faire campagne. Jusqu'à l'époque de Kennedy argent et formation semblaient aller de pair. C'est de moins en moins le cas. De même pour la corruption, l'une des caractéristiques d'un pays sous-développé: on entend dans le campus plus des considérations morales que sociologiques sur sa production. De façon générale les analyses politiques sont très souvent entachées de jugements moraux. Un anthropologue scrutera avec acuité le système politique d'une tribu lointaine, se refusant au moindre jugement de valeur, cependant il raisonnera peu sur le système qui gouverne son pays, tandis qu'il juge insupportable son injustice. C'est aussi le cas des films de Michael Moore qui sollicitent plus l'indignation que l'analyse. N'est ce pas le cas de l'ensemble de la presse? 
Generally speaking, we missed critical comments in the media written by intellectuals or former top administrators. The social status of American intellectuals appears circumscribed to academic circles; they are not expected to pass any opinion on the business of running the country. Those who hold power often have modest academic credentials, if any. One comes to miss the standardized education provided to French political leaders by the much-maligned Ecole Nationale d'Administration.

\section{Press and Media}

During our stay in the US, the Wall Street Journal was bought by Murdoch, who does not conceal his conservative political agenda and his support for the war in Iraq. Nowhere did we read any comment that the trend towards a press monopoly represents a mortal threat to democracy. The idea that the media (like some universities) can be dominated by private interests seems to be fully accepted since the days of Hearst and other media tycoons. Yet the NYT does a reasonable job at exposing the rampant corruption and other failures of the system. But the spirit is conformist, the style anecdotic, the quotations of 'anonymous sources' often appear to be made up by the editors.

\section{Corruption}

In France, we have our fair share of scandals involving politicians, shady agreements, phoney contracts, etc. Chirac enjoyed too much expensive wine while he was mayor of Paris. Juppé asked a few secretaries who were paid by the State to work for his party. Pasqua stashed some money away in a Swiss bank account. But the worst French scandals are completely dwarfed by the level of corruption that has become ordinary fare in the US. 'In Louisiana [in the aftermath of hurricane Kathrina], they skim the cream, steal the milk, hijack the bottle and look for the cow' said James Bernazzani, FBI agent (NYT, August 14 2007). Such honest agents are an endangered species: former Defense Secretary Rumsfeld 'cut some two thousand auditors from the Defense Contract Audit Agency' (Chalmers Johnson, ${ }^{[3]}$ p. 230). Presumably, the fewer auditors, the easier it will be to strike profitable deals. Yet, perhaps miraculously, the academic environment does not seem to be infected by the virus of corruption, and appears to 'have its own fabric' (TR).

\section{Taxes}

The lack of adequate signs on streets and roads is a simple consequence of Reagan- omics. Pas d'impôts, pas de panneaux (no taxes, no signs), as FF put it succinctly. Every time we got lost in the streets of Berkeley or San Francisco by lack of signs, every time we turned into the wrong direction on one of those famous ten-lane freeways, I kept thinking how much easier it would be to pay a little more taxes. One may wonder how many Americans are driving in circles in utter confusion, lost on their own roads. There must be a sizeable potential for energy savings here! Every time we listened to the endless fund-raising efforts on NPR, every time a beautiful concert was followed by blaring advertising, we remembered the advantages of public funding.

\section{Health}

Michael Moore's movie on the shortcomings of the US health care system is undoubtedly a rather crude provocation. As far as we could see, it had little impact. There is an amazing level of confidence that you can get the best health care in the US, provided you pay for it, or have a good insurance coverage, or even, so we have been told, if you have neither money nor insurance. The discrepancy between the reality and its perception is truly staggering in this area. To put it in more constructive terms: the ability of Americans to perceive positive elements against a noisy background is admirable. (By contrast, the French have an uncanny ability to perceive even minor imperfections in their earthly paradise.) How the American optimism agrees with the classification of the World Health Organization (WHO), which ranks the US health system in $36^{\text {th }}$ position between Slovenia and San Salvador, is hard to understand. Probably an indication that the WHO must be run by shady commies? (The French reluctantly admit to being first in this ranking, thus seeing the scope of their grumbling greatly reduced, much to their regret.) The US is currently the $42^{\text {nd }}$ country in the world in terms of life expectancy. Infant mortality figures are dismal. But these numbers are of little concern to the 'middle classes', and academics do not feel concerned.

\section{Denial}

Le déni de réalité est probablement la force de frappe la plus puissante des Américains. L'intelligentsia mondiale ici réunie ne parle de politique que pour répéter à l'envie la bêtise de celui qui a été chargé de la conduire par un vote réputé démocratique. De tout ce qui fermente sous cette bêtise, corruption, irresponsabilité et profit, pas un mot. De ce qui affleure de cette stupidité impériale on ne s'entretient guère: l'absence de services publics dignes de ce nom, l'incompétence des employés, les aberrations des procédures bancaires ou administratives, tout cela est donné et acquis à la fois. On ne le voit même pas. Cet aveuglement est cohérent avec la mise au naturel de l'absence de l'Etat. De même qu'on ne voit pas les composantes d'un paysage que l'on traverse chaque jour, on ne perçoit guère les tracas de la vie quotidienne qui pourraient être évités par des services publics moins médiocres.

For a European visitor, the US often strikes through a certain untidiness. One of our favourite adjectives to describe the ambient lack of rigour is 'foireux'.

L'une des raisons du caractère foireux des démarches administratives pourrait être le bas niveau de formation du petit personnel, soit finalement le bas niveau de l'école secondaire. En éducation comme en moyens de vie, le contraste est saisissant entre le très haut niveau de l'enseignement supérieur et l'état déplorable des écoles secondaires.

One quickly comes to realize that gaping potholes in pavements, poor maintenance of highways and bridges (the collapse of an Interstate highway bridge in Minneapolis in August 2007 did not really surprise anybody), are not the exclusive property of 'developing' countries.

Une promenade dans Berkeley fait réfléchir sur la définition d'un pays 'en voie de développement'. Ce terme suppose généralement la pauvreté. Or, on découvre ici qu'un pays peut être 'en voie de développement' tout en étant riche. Dans ce sens, les Américains ont toujours été et seront toujours 'en voie de développement'. Ils sont dans cette phase de l'économie de marché où la question de la répartition des richesses se pose rarement. On pourrait ainsi définir un pays 'développé' non pas comme un pays riche mais comme un pays qui cherche à distribuer ses richesses le moins inégalement possible. Dans ce sens, l'Europe d'après-guerre, ruinée et misérable, était certainement plus 'développée' que les USA d'aujourd'hui. Dans le campus de Berkeley et ses alentours, le 'développement' semble régner en toute chose: la santé éclatante de la population étudiante, la courtoisie des automobilistes, la priorité accordée aux piétons, la banalisation de la concentration intellectuelle au café 'La Strada', le sigle 'CAL' des tee-shirts transformés en maillots d'équipe d'interconnaissance, le prix du stationnement des voitures, le mélange des yeux bridés et des crinières blondes, la légèreté de l'air entre le parfum des roses et l'ombre des séquoias... Il suffit de descendre (au sens propre et figuré) la University Avenue pour découvrir l'envers du décor: une population 
'afro-américaine' (comprenez noire) courroucée et peu disciplinée, irrespectueuse de la 'privacy', le tumulte des sirènes tempétueuses d'un train toujours en retard, des vieillards hagards traînant leur vie dans un cadi, des jeunes aux visages émaciés transformés en pancartes publicitaires aux carrefours défoncés. Ici, les 'sans domicile fixe' ne sont pas des clochards mais plutôt des malades mentaux, des 'laissés pour compte' au sens strict: le déficit budgétaire en chair et en os, ceux-ci rongés, celle-là obèse. Le sousdéveloppement n'est pas dans ce monde ténébreux en lui-même, mais dans sa conjonction avec la clarté du campus. Comme si on avait mis ensemble l'univers de Zola et celui de Proust. Les 'gueules noires' et le thé à la madeleine.

The streets of San Francisco and Berkeley (separated by less than ten miles across the Bay) are populated by scores of homeless people. In San Francisco and Berkeley, the extent of the problem is readily explained by our hosts: the local city councils are more generous than elsewhere in the US, the climate milder, and the citizens more liberal. The appalling health condition of the homeless must be a matter of individual freedom, since they 'can get free health care in the emergency room of any hospital'. The bills, so we have been told, are simply sent to the city councils, and paid out of general tax revenues. How much of this rosy picture should we believe?

\section{Noise, Cars, and other Substitutes}

The freight and passenger trains that travel through Berkeley at all times of day and night continuously blow their powerful horns as if the tracks were full of buffalos. Nobody seems to object. By contrast, the French go out of their way so that their metros and trains are virtually inaudible. In Paris, we've had a team of acoustic engineers sent by the Préfecture who, at our request, came to our apartment to measure the noise level generated by the ventilators of a nearby hospital. As a result, the Hôpitaux de Paris were compelled to install a sophisticated noise-abatement system.

In Berkeley, the streets are full of rattling old trucks and brand-new sports utility vehicles that have no utility whatever and are no good for any sport, but have engines that roar like grizzly bears. Some believe that big cars may be considered as substitutes for male sex organs.

Il me semble que le besoin de prothèse pénienne est proportionnel à la répression sexuelle, et aux Etats-Unis celle-ci doit être lourde à supporter. Petit délire sur la manière compliquée de prendre de l'essence dans une station-service: il faut faire des

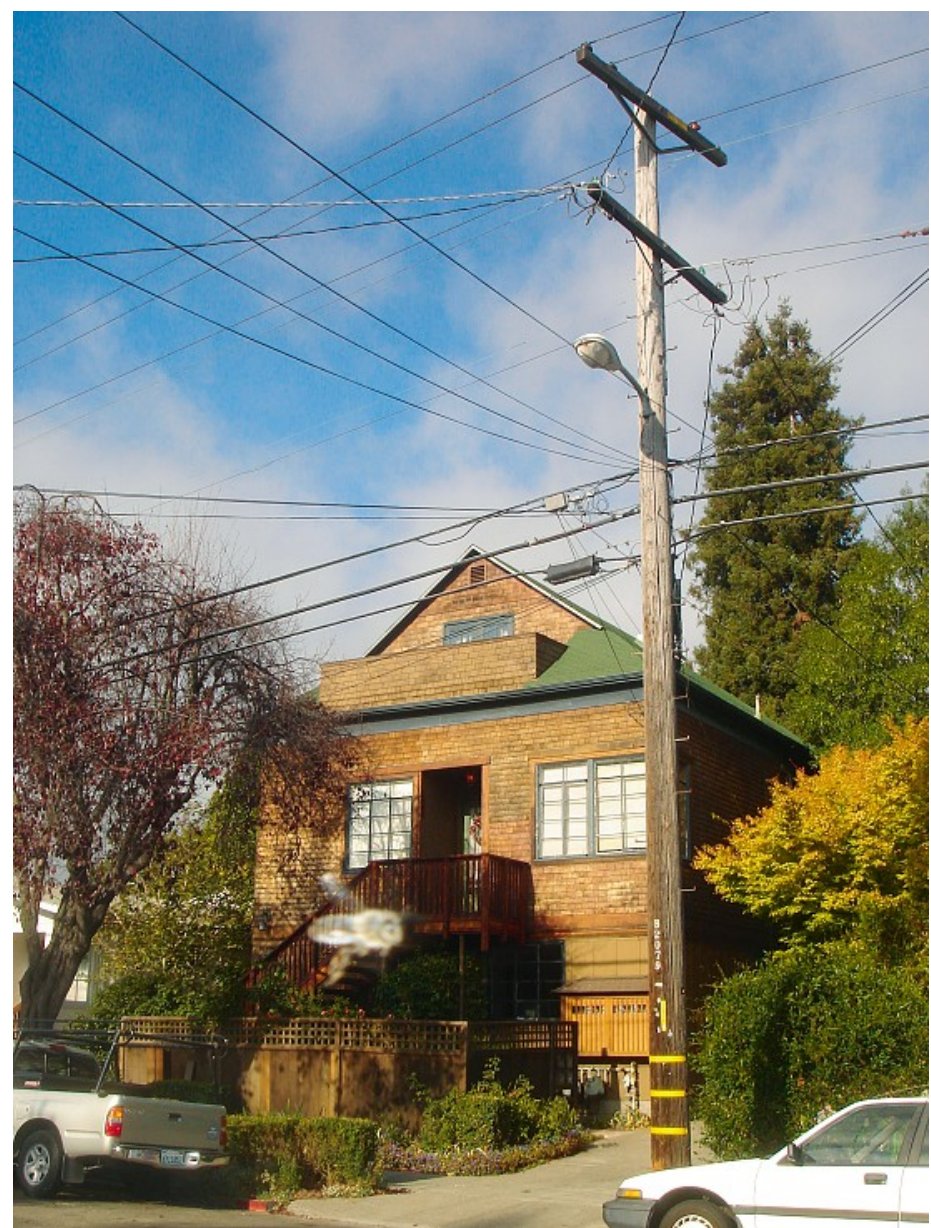

During our sabbatical in Berkeley, we stayed in an apartment on Mc Gee Avenue, a few miles West of the campus of UC Berkeley

allers et retours, payer d'avance, indiquer son code postal à une machine. Peut-être n'est-ce pas très réjouissant d'avoir à prendre de l'énergie pour renouveler la puissance de son organe? Dans l'importance accordée à la voiture, il y a peut-être un facteur culturel: on a l'impression que les Américains prennent leur voiture comme le cow-boy prenait son cheval, pour le moindre déplacement. Mieux, la voiture apparaît comme le prolongement de leur corps: on pense à ces Amérindiens qui percevaient l'homme blanc à cheval comme un centaure. Il est d'ailleurs frappant de comparer la propreté immaculée des voitures aux nidsde-poule des rues que celles-ci parcourent.

\section{Imperialism}

A Berkeley le visiteur ne perçoit pas le moindre signe d'un quelconque «impérialisme américain». On se demande même comment croire les journaux, les militants et autres bien pensants quand ils vous disent que les Yankees dominent le monde et nous imposent leur loi d'airain. Les gens déambulent dans les rues sans épée ni panache. Ils s'offrent tout sourire à votre étrangeté. La carte de Berkeley, comme celles d'autres villes américaines, ressemble à un carton de jeu de l'oie, à un ticket de tiercé sur lequel on cocherait l'adresse où l'on se rend. On a l'impression qu'ils ont délégué les conflits et les classes à un extérieur lointain: celui de l'autre côté de la rue. Comment penser dans cette atmosphère paisible à tous ces soldats blonds ou noirs qui en Irak sautent sur des bombes et torturent des Arabes qui se vivent en résistants?

Gore Vidal has listed 201 overseas military operations between 1945 and 2001 in which the US struck the first blow (Chalmers Johnson, ${ }^{[3]}$ p. 18). It is striking that the American identity seems to require the existence of an enemy, or even the 'construction' of an opponent out of nowhere. All nation-states have similar needs, but many find that Olympic games, soccer matches, rugby and tennis tournaments suffice to build their identity. The US needs greater challenges, like Communism and Islamic fundamentalism. Some sources estimate that the overall military spending of the US represents more than the total military spending of all other countries in the world added together (CJ). 'We simply cannot afford this' (AJ). No wonder the federal state appears absent from many strategic areas. By contrast, Europeans appear much more absorbed with the business of enhancing 
their standards of living, and 'get something in return for paying their taxes', in particular in terms of public health and social security (AJ).

L'armée américaine ne sert pas seulement à faire la guerre. Elle joue un rôle central dans la reproduction du système économique: elle permet aux USA d'avoir une dette énorme, d'empêcher que les fonds de pension ne soient captés par ceux qui les alimentent, comme les Chinois par exemple; elle permet de protéger le prix des produits américains tout en imposant la concurrence à ceux des autres; elle permet de polluer l'atmosphère quatre fois plus que les autres, etc. L'armée joue un rôle finalement très primitif d'intimidation et de protection médiévale du château-fort. On peut même se demander si les interventions militaires ne sont pas finalement de simples manouvres pour préparer la grande guerre qui est prévue au cas où l'on contesterait aux USA ses privilèges exorbitants.

\section{Violence}

Dans l'univers de Berkeley, il n'y a aucune trace de violence dans le comportement quotidien. Everybody is so polite and considerate! Les gens y semblent plus pacifiques qu'en France (du moins à Paris) où l'on souffre d'agressivité dans la rue, la circulation, et l'administration. Mais le campus de CAL n'est guère significatif. Et dès qu'on s'en éloigne, les signes de violence se multiplient, en particulier dans les quartiers noirs où la violence n'est pas forcément agressive mais simplement expressive: on parle plus fort, on roule plus vite, on se bouscule...

After a late-evening walk all the way to San Pablo Avenue in the first week of our stay, I decided to stay indoors at night. Whether the fear of violence has a statistical foundation or not is immaterial: the fear determines one's behaviour.

\section{No Bankruptcy in Sight}

CJ's predictions can be summed up in few words: "the US will go bankrupt as soon as the Chinese get tired of being paid in increasingly worthless dollars." (This argument seems to ignore China's interest in keeping the US economy going.) The impending disaster could be compared with what happened to Germany in the 1920s. Bankruptcy would not imply the end of the US, but a severe cut in its standards of living, and could only be overcome by a profound renewal of the political structure. Let's hope, should the inevitable end of the US indeed occur

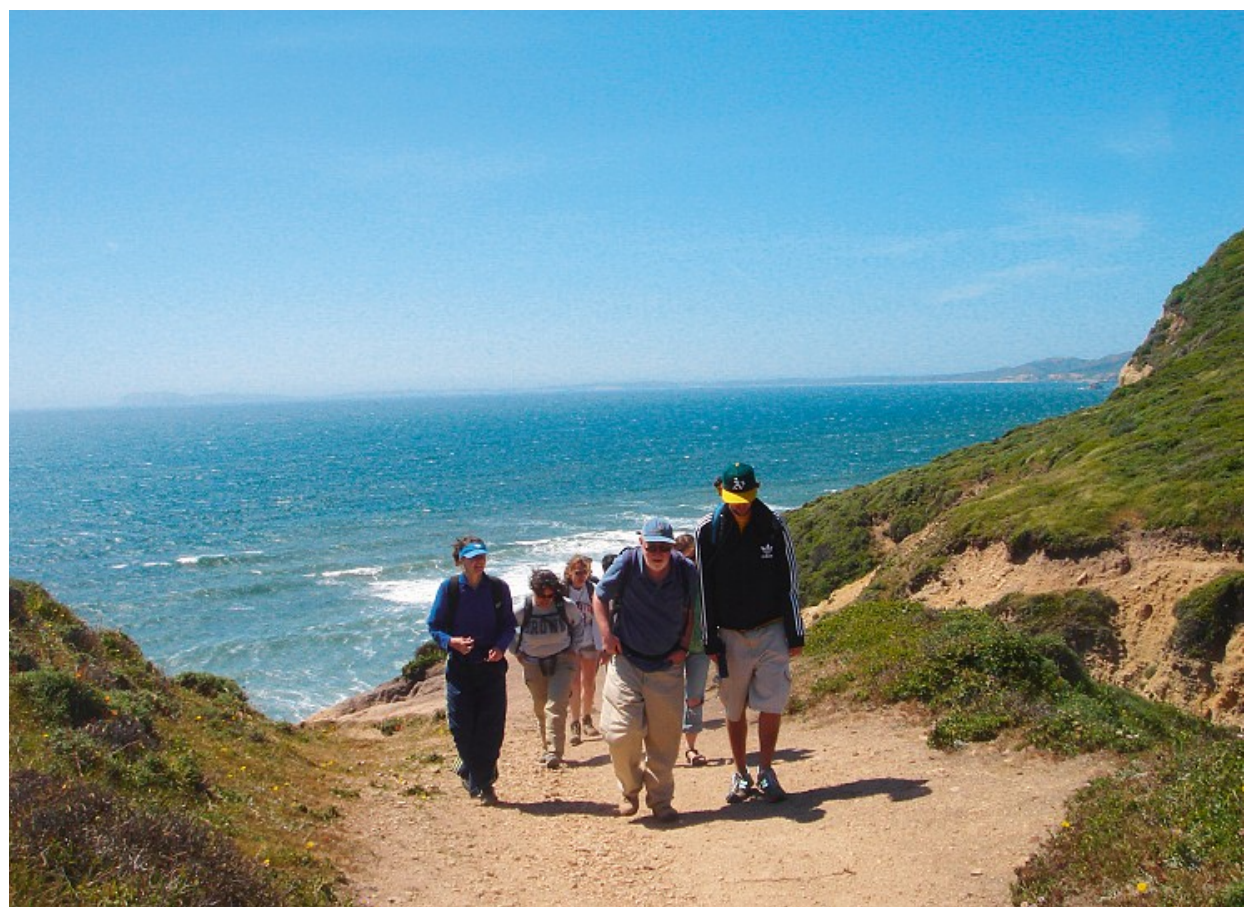

Excursion of Graham Fleming's group near Point Reyes, on the Pacific Coast north of the Bay area

soon, that we avoid another Third Reich on the way to renewal.

There is no evidence of any impending bankruptcy at UCB. If anything, the war seems to be good for the economy (PV), federal money keeps flowing, research proposals continue to be funded, and the Department of Energy is willing to inject nearly unlimited funds in research (GF).

\section{Religion}

The expression 'laïcité, which is constantly used in France, does not appear to have a good English translation (since 'secularism' has a different meaning), other than clumsy negative forms such as 'a-religiousness'. (On voit bien que la traduction anglaise de ce mot dénote un manque. En France on ne dit pas "a-religieux" mais "laïc”: l'adjectif est positif.) Yet, like France and many other European countries, the US wisely holds that religion is a private matter, and the separation of state and church appears to be laid down in the Constitution. Yet the press speaks of a fundamentalist variety of Christianism that apparently invades many areas of public interest. The concept of intelligent design, the ideas on abortion, on stem-cell research, etc., are rather scary from a French perspective. Why do so many intellectuals tolerate this nonsense? Perhaps it makes sense from their point of view.

On ne trouve pas d'expression de cette religiosité à Berkeley. Certes le nombre et la variété des lieux de culte sont impressionnants. Mais ils expriment surtout une sorte de folklore local, un mysticisme ou- vert de type new age. On est tenté de faire un lien entre la concentration spectaculaire à la fois de lieux de science et de lieux de croyance. Est-ce comme pour l'inscription 'in God we trust' qui figure sur les dollars, faisant contrepoids à une pratique spéculative contraire au christianisme original?

\section{Enlightenment}

One sometimes hears in France that the US has forgotten much about the enlightenment that presided over its birth. Yet some ideas of the 18th century still linger on in the US. Take Benjamin Franklin, who wrote in 1759: "Those who give up essential liberty to purchase a little temporary safety deserve neither liberty nor safety." (cited by C. Johnson, ${ }^{[3]}$ p. 89). Or consider James Madison, one of the architects of the Constitution, in 'Political observations' (1795): "Of all the enemies of true liberty, war is, perhaps, the most dreaded, because it comprises and develops the germs of every other." It is striking that similar language can still be found in today's comments on National Public Radio and editorials of the New York Times, much more so than in the European press.

\section{Is the US Leading the Way?}

I like to think that, for the better or the worse, the US is often more 'advanced' than Europe, in the chronological sense, in many patterns of behaviour. After all, it is in California that lead-free gas was introduced, that cars were first fitted with catalytic con- 
verters, that smoking was banned. Many playful things like surfing, skate boarding, roller skating, windsurfing, etc., were also invented there. Not to mention laptops, walkmen, iPods, etc. But not all such inventions are playful. The prospect that Reaganomics, private medicine, private education, private UPS and FedEx services, etc., might be blowing over to Europe is something to reckon with. Likewise, the decay of the post office, of public transportation, energy, education, health, retirement, and social security, all of these may be coming our way, whether we like them or not.

\section{Cultural Misunderstandings}

Perhaps the most striking examples of cultural differences can be found in the area of sports. While waiting for a pizza, we watched some baseball on TV. For the non-initiated, this must be the most uninspired, soporific and boring sport ever invented. It is static, being mostly composed of intervals, full of self-conscious theatrical narcissism (e.g. the endless rectifications of the pitcher's cap and T-shirt sleeves), and seems to require little interactive skills, since each player appears to be doing his thing on his own. The remarkable thing is that Americans (even educated ones like SB) marvel with excitement about this game. Back in 1994 in Tallahassee, when Florida State had the best college football team in the country, I was similarly puzzled how people whom I sincerely value (such as AM and MM) could appreciate such a boring game. When visiting Paris recently, the same American friends marvelled about the omnipresence of restaurants in France. Clearly, initiation is a prerequisite for appreciation, for sports as much as for food and wine.

\section{Rest and Recreation}

Berkeley and its surroundings must be one of the most desirable places to live on earth. Unlike most of the US, it is never cold, never hot, and never humid. UC's campus harbours some marvels of architecture. There are an astounding variety of flowers everywhere, in the streets, along the highways, in the parks, in the front and back yards. I'll miss my early-morning walks to Andronico's to pick up the daily issue of the New York Times. We saw many wonderful homes: spacious but never pretentious, beautiful yet functional, often with breathtaking views of the Bay. We drove in a gas-guzzling convertible Ford Mustang from May to June, and a super-efficient Toyota Solara from July to August. We travelled up and down the Pacific coast, North to Mendocino, the Timber Cove Hotel near Jenner, Russian River,
River's End, Point Reyes, Stinson Beach, Tennessee Valley, Tiburon, Angel Island, Sausalito, and South to San Juan Bautista, Asilomar, Big Sur, Pfeiffer Beach, and the Park Hyatt near Carmel (for drinks only!) Towards the East, we visited Lake Tahoe where we attended a crazy Renaissance Revival festival, and had a look at Squaw Valley. Towards the South-East we visited Yosemite Valley, Glacier Point, and drove all the way over the Tioga pass to Mono Lake, Mammoth Lakes, and the Devil's Postpile. We experienced many surprising gastronomic experiences: in no area has the US, or at least the Bay area, evolved more dramatically for the better. We saw three opera performance ('Don Giovanni' and Gluck's 'Iphigénie en Tauride' in San Francisco, and a refreshing 'Aida' in Berkeley), a few movies, read a fair amount of fiction (including some romans de gare such as Douglas Kennedy's 'The pursuit of happiness', Khaled Hosseini's 'Kite runner', and Bill Bryson's 'Notes from a big country' ${ }^{[4]}$ ), and swam an incredible number of laps in the beautiful Hearst and Golden Bear pools.

\section{Acknowledgements}

We are deeply indebted to Alex and Ditsa Pines, who must be the most generous and talented hosts on earth, Charles Harris (Dean), Mary Ann Ekman (Dean of Graduate Studies), Jeff Reimer (Chair of Chemical Engineering) David Chandler (Chair of the Miller Institute), Erwin Hahn, Graham Fleming, Ignacio Tinoco, Carlos Bustamante, Robert Bergman, Gabor Somorjai, Peter Vollhardt, Marcia Majda, David Wemmer, Jhih-Weh Chu, Dmitri Budker, Bruce Ames, Harry Swinney (Texas), Lonnie Thompson (Ohio State), the staff of the Miller Institute, John Searle the philosopher, Betty Howell the explorer, Guy and Karen Benveniste. Among the social anthropologists, we shall dearly remember Stanley Brandes, Bill and Jennifer Hanks, Marisol de la Cadena, Stephen Boucher, Michael Wintroub, Hélène Mialet, and Stanley Horowitz at UC Press. We learned a great deal from Alyse Jacobson, without whose talents the Pinenuts would not be what they are, not least thanks to her sense of humour. We also liked the company of Walt the carpenterlinguist-interpreter, Joanne the landlady, Edward the repairman-philosopher, Morgan the sailormusician, Albert the swimmer-law-student. We owe a lot to the staff and editors of the New York Times (NYT), the staff of KPFA on $94.1 \mathrm{MHz}$ (in particular Amy Goodman of 'Democracy Now'), National Public Radio (NPR on 91.7 $\mathrm{MHz}$ ), KDFC (who manage to intersperse some classical music between all-invading advertising on $102.1 \mathrm{MHz}$ ), the Metropolitan Opera in New York who produce a commercialfree program on Sirius satellite radio. We owe virtually nothing to any $\mathrm{TV}$, save perhaps the Public Broadcasting Station (PBS) who had the good taste to show some material from the BBC. Otherwise, our feeble attempts at zapping had the most powerful soporific effects. Simone de Beauvoir, ${ }^{[1]}$ Chalmers Johnson, ${ }^{[3]}$ Ralph Ellison ('Invisible Man'), Michael Moore ('Sicko'), gave insight from different viewpoints. Others offered some unexpected comments: Ray Freeman ("But they have good people, you know"), Richard Ernst ("Switzerland would do the same things [as the US] if it were a world power"), Kurt Zilm (Yale), Dan Weitekamp (CalTech), Phil Grandinetti (Ohio State University), JeanMaurice Mallet and Fabien Ferrage (Paris), Tom Rizzo (Lausanne), Alan and Marilyn Marshall (Tallahassee), and Anatole Abragam (Paris), from whom ${ }^{[5]}$ we surreptitiously borrowed the title of this text.

Received: March 13, 2008

[1] Simone de Beauvoir, 'L'Amérique au jour le jour: 1947', Gallimard, Paris, 1997.

[2] J. Galinier et A. Molinié, 'Les NéoIndiens. Une religion du IIIe millénaire', Odile Jacob, Paris, 2006.

[3] C. Johnson, 'Nemesis: the Last Days of the American Republic', Metropolitan Books, Henry Holt and Company, New York, 2007.

[4] B. Bryson, 'Notes from a big country', Black Swan, New York, 2001.

[5] A. Abragam, 'De la physique avant toute chose', Odile Jacob, Paris, 1987. 